\title{
Effects of arbuscular mycorrhizae on microbial population and enzyme activity in replant soil used for watermelon production
}

\author{
M. Zhao, M. Li, R. J. Liu* \\ Institute of Mycorrhizal Biotechnology,Qingdao Agricultural University,Qingdao 266109, P.R.CHINA \\ "Corresponding Author: e-mail: liurj@qau.edu.cn, Tel: +86-0532-88030113 , Fax.+86-0532-86080221
}

\begin{abstract}
Arbuscular mycorrhizal (AM) fungi are ubiquitous fungi distributed widely in soil ecosystems. It has been showed that AM fungi play an important role in improving soil nutrition and enhancing crop disease resistance, which have great application potentials in overcoming crop replant problems. In order to evaluate the effects of AM fungi on soil microbe population and soil enzyme activities in replant soils, three replant soils respectively with 3, 7, and 12 watermelon (Citrullus lanatus) replanting years were employed to be investigated. Results showed that the total soil microbe, bacteria, and actinomycete population, and the activities of soil proteinase, polyphenoloxidase, urease, and saccharase in replant soils gradually declined, while the fungal population, and the fungi/total microbe ratio increased, as replanting years rose. In each replant soil, the inoculation with AM fungus Glomus versiforme enhanced soil bacteria and actinomycete population, and decreased the fungal numbers, and the fungi/total microbe ratio in replanting soils, and improved soil proteinase, polyphenoloxidase, urease, and saccharase activities, compared with controls. That contributed to the relative equilibrium of the three kinds of soil microorganism populations. It is concluded that the AM fungal inoculation can reduce watermelon replant problems through effectively modifying the soil microbe population and community structure, and increasing the soil enzyme activities.
\end{abstract}

Keywords: arbuscular mycorrhizae fungi; watermelon; greenhouse; soil microbial population; soil enzyme activity

\section{Introduction}

There are many reasons that cause crop replant problems, the main one is the non equilibrium of soil microbe community structures, which results in reducing crop yield and soil quality. Under replant conditions, crop root secretion and litter decayed materials provide rich nutrients for the pathogens, meanwhile, the long stage of suitable protective cultivation environments establish good reproductive condition to the pathogens, hence the pathogenic population continue to increase (Chin et al., 1994), and soil-borne diseases are aggravated. And this change varies as the replant time rise. Meanwhile, under protective cultivation condition when pest become serious, the large amount of pesticides used result in damaging crop growth environment, disbenefiting to soil microbial population and organic matter. While the natural equilibrium of soil microbial community and inorganic components is broken by the replant cropping, then the soil-born pathogen develops and the soil-born disease overspreads. As one of the important parameters of characteristic soil biological characters, soil enzyme activities reflect soil nutrient transformation status, appear higher complexity due to be affected by many soil factors, and are directly much influenced with minor elements, organic matter and available nitrogen (Cao et al., 2002). It was proved that the soil microbe population and soil enzyme activities were changed in watermelon replant soil (Zhao et al., 2008).

Soil fumigation is banned due to high cost and environmental concerns and long term fallow is strongly recommended before planting, but growers are not willing to wait in intensive production areas. It has been showed that arbuscular mycorrhizal (AM) fungi can change soil microbe species and ratios, and impact on the rhizosheric microbe community (Linderman et al., 1996). In fact, the rhizospheric microbes could be influenced directly or indirectly by AM fungi, i.e. under the precondition of little change of the species, the microbe population was changed, the new equilibrium was established, and their activities were increased (Linderman, 1988; Kothari et al., 1991). AM fungi have positive effects on replant diseases in grape or apple orchard (Camprubí et al., 2008; Raj and Sharma, 2009). Inoculation with vesicular-arbuscular mycorrhizal fungi Glomus etunicatum was successful 
during the first 6 months of growth only when apple seedlings were grown for the first three weeks in a sterile substrate (sand-soilpeat). When young grafted apple trees were inoculated directly in orchard soil with Apple replant disease under non-sterile conditions, the effect of inoculation was negligible after 6 months. There were significant differences in the composition of the rhizosphere microflora after 6 months, especially between the soil with Apple replant disease and the virgin soil (Catská and Taube-Baab, 1994). Pre-inoculated peach seedlings transplanted in non-replant soils showed greater initial growth in the first year. Plant height, and lateral shoot length and number was highest in non-replant soils irrespective of mycorrhizal pre-inoculation. Similarly, biomass yield was significantly higher in seedlings in non-replant soils (Rutto and Mizutani, 2006). Inoculation with AM fungi can also change the bacteria and actinomycete numbers on the root surface and in the rhizosphere. While the benefit rhizospheric microbe which coexists with AM fungi may enhance AM fungal colonization. The author once found that AM fungi improved watermelon (Citrullus lanatus) seedling growth, and effectively decreased fusarium wilt diseases under replant conditions. However, we know little information on the influence of AM fungi on replant soil microbe population.

The purpose of the study was to investigate the effects of AM fungi on soil microbial population, the fungi/total microbe ratio, and the soil enzyme activities in watermelon replant soil, in order to provide the basis for further studying the mechanism of AM fungus overcoming replant problems.

\section{Materials and methods}

2.1 Materials: Seeds of watermelon (Citrullus lanatus) cultivar No. 1 Jingxin that was resistant to fusarium wilt disease were soaked in water for 12 hrs after being surface-sterilized with 70\% ethanol, then buding under 28-30 for sowing. Fresh spores and colonized root pieces from 4-month-old pot cultures of AM fungus Glomus versiforme on Trifolium repens L. were used as inocula. Replant soil with 3, 7, and 12 replant years was collected respectively from a plastic shield field in Raogou, Changle County, Shandong Province. Clay pots $(25 \times 30 \mathrm{~cm})$ and seedling trays were surface-sterilized with $40 \%$ formaldehyde solution for growing watermelon seedlings.

2.2 Experimental design: Experiments were carried in a sunlight-greenhouse. The replant soil with 3, 7, and 12 years was inoculated with or without Glomus versiforme (Gv) respectively, with 6 treatments. Each treatment was replicated in 30 pots, with randomly arranged.

2.3 Sowing and inoculation: Two budded seeds of watermelon were put in a tray hole filled with sterilized peat mixed with 5000 IPU of Glomus versiforme inocula(Liu and Luo, 1994), while the control was added the sterilized inocula with 10ml filter solution of the inocula. The temperature was $26^{\circ} \mathrm{C} / 15^{\circ} \mathrm{C}$ (Day/Night). Seedlings with 3 leaves were transplanted into the pots. One seedling was maintained in each pot. Plants were watered once every 2 days, and 30\% in strength of Hoagland nutrient solution without phosphorus was added once every 2 weeks.

2.4 Measuring soil microbial population: Soil samples were collected at the flowering, fruiting and harvest stages respectively, to isolate, determine the numbers of bacteria, actinomycete, and fungi. Beef extract peptone, No.1 Gao, and PDA was employed respectively to isolate bacteria, actinomycete, and fungi. Dilute plate counting method was used to measure the microbe numbers (Zhao and He, 2002). The fungi/total microbe ratio was the value of the fungal number divided by the total microbe number.

2.5 Assaying of soil enzyme activity: Soil samples were collected at the flowering, fruiting and harvest stages respectively, to determine the soil enzyme activity. Activities of proteinase, polyphenoloxidase, urease, and saccharase were determined respectively with ninhydrin colorimetry, potassium dichromate colorimetry, indophenol blue photometric method, and dinitrosalicylic acid colorimetry (Guan, 1986).

2.6 Statistical analysis: The data were subjected to Analysis of Variance (ANOVA) using the Statistical Analysis Systems (SAS 6.12) package. Comparison of multiple means was performed using the least significant difference (LSD) test at the $5 \%$ level.

\section{Results and discussion}

As the replanting year rose, total soil microbe population, bacterium and actinomycete numbers reduced, while the fungal population and the fungi/total microbe ratio increased in the present experiment. The results showed that AM fungal inoculation in watermelon replant soil could significantly promote the population of bacteria, actinomycete, and the total microbes, and decrease the fungal population and the fungi/total microbe ratio. In various growth and development stages of watermelon, effects of AM fungi on soil microbe population in watermelon replant soil with different replanting years showed the similar pattern. For instance, the total microbe population in the treatment with AM fungi was significantly higher than that of control at the flowering period of watermelon, indicating that AM fungi would enrich the microbe numbers in replant soil.

In replant soils with various replanting years, the AM fungal inoculation treatments showed less fungal numbers, more bacteria and actinomycete, and lower the fungi/total microbe ratio (from $1 / 2$ to $1 / 4$ ) compared with control (Table 1). It was suggested that AM fungi can be beneficial to keeping a suitable proportion of microbes in replant soil on some degree.

At the fruit setting stage of watermelon plants, soil bacterium, actinomycete, fungal, and the total microbe population significantly increased (Table 2). Compared with the fruit setting stage, the soil bacterium, actinomycete, and the total microbe population significantly reduced, while the fungal number and the fungi/total microbe ratio increased at harvest stage (Table 3). And the AM fungal treatment gave the same effects as above mentioned. These results supported the findings by Secilia and 
Bagyaraj (1988). As we know that the mycorrhiza formation impacts greatly the rhizospheric microbe community and population, second to the influence by plant species (Linderman et al., 1996). AM fungi may directly or indirectly influence the rhizospheric microbe, i.e. under the condition of no great changes of microbe species, alter their population, let forming a new equilibrium, and enhance their activities (Kothari et al., 1991). This was very important in stabilization of the microbe equilibrium during the whole development of crops.

Table 1 Effects of AM fungi on soil microbe population in watermelon replant soil at the flowering period of watermelon plants

\begin{tabular}{cccccc}
\hline Treatments & $\begin{array}{c}\text { Total microbe } \\
\text { numbers } \\
\left(\times 10^{4} \mathrm{CFU} \cdot \mathrm{g}^{-1}\right. \\
\text { dry soil })\end{array}$ & $\begin{array}{c}\text { Number of } \\
\text { fungi } \\
\left(\times 10^{4} \mathrm{CFU} \cdot\right. \\
\left.\mathrm{g}^{-1} \text { dry soil }\right)\end{array}$ & $\begin{array}{c}\text { Number of } \\
\text { bacteria } \\
\left(\times 10^{4} \mathrm{CFU} \cdot\right. \\
\left.\mathrm{g}^{-1} \text { dry soil }\right)\end{array}$ & $\begin{array}{c}\text { Number of } \\
\text { actinomycete } \\
\left(\times 10^{4} \mathrm{CFU} \cdot\right. \\
\left.\mathrm{g}^{-1} \mathrm{dry} \mathrm{soil}\right)\end{array}$ & $\begin{array}{c}\text { Fungi / Total } \\
\text { Microbe ratio }\end{array}$ \\
\hline 3-CK & $1705.6 \mathrm{c}$ & $3.1 \mathrm{c}$ & $1107.5 \mathrm{c}$ & $595.0 \mathrm{c}$ & $0.002 \mathrm{~cd}$ \\
3-AM & $2769.2 \mathrm{a}$ & $1.7 \mathrm{f}$ & $1705.0 \mathrm{a}$ & $1062.5 \mathrm{a}$ & $0.001 \mathrm{e}$ \\
7-CK & $1417.4 \mathrm{~d}$ & $4.9 \mathrm{~b}$ & $1080.0 \mathrm{~d}$ & $342.5 \mathrm{~d}$ & $0.004 \mathrm{~b}$ \\
7-AM & $2039.9 \mathrm{~b}$ & $2.4 \mathrm{e}$ & $1332.5 \mathrm{~b}$ & $705.0 \mathrm{~b}$ & $0.001 \mathrm{~d}$ \\
12-CK & $976.6 \mathrm{f}$ & $6.6 \mathrm{a}$ & $707.5 \mathrm{f}$ & $262.5 \mathrm{f}$ & $0.007 \mathrm{a}$ \\
12-AM & $1117.7 \mathrm{e}$ & $2.7 \mathrm{~d}$ & $822.5 \mathrm{e}$ & $292.5 \mathrm{e}$ & $0.002 \mathrm{c}$ \\
\hline
\end{tabular}

* Means in each column followed by different letters are significantly different based on LSD test $(P<0.05)$.

3-CK, replant soil with 3 replanting years; 3-AM, inoculating AM fungi in replant soil with 3 replanting years; 7-CK, replant soil with 7 replanting years; 7-AM, inoculating AM fungi in replant soil with 7 replanting years; 12-CK, replant soil with 12 replanting years; 12-AM, inoculating AM fungi in replant soil with 12 replanting years.

Table 2 Effects of AM fungi on soil microbe population in watermelon replant soil at the fruit setting stage of watermelon plants

\begin{tabular}{|c|c|c|c|c|c|}
\hline Treatments & $\begin{array}{c}\text { Total microbe } \\
\text { numbers } \\
\left(\times 10^{4} \mathrm{CFU} \cdot \mathrm{g}^{-1}\right. \\
\text { dry soil })\end{array}$ & $\begin{array}{c}\text { Number of } \\
\text { fungi } \\
\left(\times 10^{4} \mathrm{CFU} \text {. }\right. \\
\left.\mathrm{g}^{-1} \text { dry soil }\right)\end{array}$ & $\begin{array}{c}\text { Number of } \\
\text { bacteria } \\
\left(\times 10^{4} \mathrm{CFU} \text {. }\right. \\
\left.\mathrm{g}^{-1} \text { dry soil }\right)\end{array}$ & $\begin{array}{c}\text { Number of } \\
\text { actinomycete } \\
\left(\times 10^{4} \mathrm{CFU} \text {. }\right. \\
\left.\mathrm{g}^{-1} \text { dry soil }\right)\end{array}$ & $\begin{array}{l}\text { Fungi / Total } \\
\text { microbe ratio }\end{array}$ \\
\hline 3-CK & $4371.7 \mathrm{c}$ & $6.2 \mathrm{c}$ & $3523 \mathrm{~d}$ & $642.5 \mathrm{~b}$ & $0.0014 \mathrm{~b}$ \\
\hline 3-AM & $6612.3 \mathrm{a}$ & $3.8 \mathrm{~d}$ & $5801 \mathrm{a}$ & $807.5 \mathrm{a}$ & $0.0006 \mathrm{~d}$ \\
\hline 7-CK & $4227.2 \mathrm{~d}$ & $7.2 \mathrm{~b}$ & $3625 d$ & $595.0 \mathrm{c}$ & $0.0017 \mathrm{ab}$ \\
\hline 7-AM & $5361.1 \mathrm{e}$ & $5.6 \mathrm{~cd}$ & $4613 \mathrm{~b}$ & $742.5 \mathrm{a}$ & $0.0010 \mathrm{c}$ \\
\hline 12-CK & $3666.9 \mathrm{f}$ & $8.4 \mathrm{a}$ & 3416 e & $242.5 \mathrm{e}$ & $0.0023 \mathrm{a}$ \\
\hline 12-AM & $4539.6 \mathrm{~b}$ & $6.6 \mathrm{c}$ & 3998 c & $535.0 \mathrm{~d}$ & $0.0015 \mathrm{~b}$ \\
\hline
\end{tabular}

Table 3 Effects of AM fungi on soil microbe population in watermelon replant soil at the harvesting time of watermelon

\begin{tabular}{|c|c|c|c|c|c|}
\hline Treatments & $\begin{array}{c}\text { Total microbe } \\
\text { numbers } \\
\left(\times 10^{4} \mathrm{CFU} \cdot \mathrm{g}^{-1}\right. \\
\text { dry soil }) \\
\end{array}$ & $\begin{array}{l}\text { Number of } \\
\text { fungi } \\
\left(\times 10^{4} \mathrm{CFU} \text {. }\right. \\
\left.\mathrm{g}^{-1} \text { dry soil }\right) \\
\end{array}$ & $\begin{array}{c}\text { Number of } \\
\text { bacteria } \\
\left(\times 10^{4} \text { CFU. }\right. \\
\left.g^{-1} \text { dry soil }\right) \\
\end{array}$ & $\begin{array}{c}\text { Number of } \\
\text { actinomycete } \\
\left(\times 10^{4} \mathrm{CFU} \text {. }\right. \\
\left.\mathrm{g}^{-1} \text { dry soil }\right)\end{array}$ & $\begin{array}{l}\text { Fungi / Total } \\
\text { microbe ratio }\end{array}$ \\
\hline 3-CK & $3116.6 \mathrm{~d}$ & $9.1 \mathrm{~d}$ & $2545.0 \mathrm{~b}$ & $562.5 \mathrm{~b}$ & $0.003 \mathrm{c}$ \\
\hline 3-AM & $4259.5 \mathrm{c}$ & $4.5 \mathrm{f}$ & $3425.0 \mathrm{a}$ & 830.0 a & $0.001 \mathrm{e}$ \\
\hline 7-CK & $1772.3 \mathrm{~b}$ & $9.8 \mathrm{~b}$ & $1367.5 \mathrm{~d}$ & $395.0 \mathrm{~d}$ & $0.006 \mathrm{~b}$ \\
\hline 7-AM & 2458.7 a & $6.2 \mathrm{e}$ & 1970.0 c & $482.5 \mathrm{c}$ & $0.003 \mathrm{c}$ \\
\hline 12-CK & $1294.7 \mathrm{f}$ & $12.2 \mathrm{a}$ & $1150.0 \mathrm{e}$ & $132.5 \mathrm{f}$ & $0.010 \mathrm{a}$ \\
\hline 12-AM & $1522.1 \mathrm{e}$ & $9.6 \mathrm{c}$ & $1307.5 \mathrm{~d}$ & $205.0 \mathrm{e}$ & $0.006 \mathrm{~b}$ \\
\hline
\end{tabular}

* Means in each column followed by different letters are significantly different based on LSD test $(P<0.05)$.

3-CK, replant soil with 3 replanting years; 3-AM, inoculating AM fungi in replant soil with 3 replanting years;

7-CK, replant soil with 7 replanting years; 7-AM, inoculating AM fungi in replant soil with 7 replanting years;

12-CK, replant soil with 12 replanting years; 12-AM, inoculating AM fungi in replant soil with 12 replanting years.

There are many mechanisms of inhibiting plant pathogens by AM fungi; one of them is that AM fungi change the rhizospheric microbe population and community structure. After colonization on plant roots with AM fungi, the quantity of rhizospheric microbes significantly increased (John, 2001). The number of both rhizospheric bacteria and actinomycete enhanced when plant formed mycorrhizas, while the dominant species composition also changed (Secilia and Bagyaraj, 1987). There may be two 
pathways for AM fungi to change microbe community structure, the first one is that the AM fungal hypha secretion directly impacts microbe community structures; the another one is that both AM fungi in roots and on the roots alter plant physiological and biochemical processes, then directly or indirectly change the plant root secretion (Bansal and Mukerji, 1994; Andrade et al., 1998; Bais et al., 2008; Badri and Vivanco, 2009), thus alter those structures (Zhu et al., 2005). In present study, AM fungi significantly decreased the fungal number and the fungi/total microbe ratio, increased the amount of bacteria and actinomycete, which may effectively alleviate the replant problem due to the microbe nonequlibrium.

In our experiment we further observed that activities of soil proteinase, polyphenoloxidase, urease, and saccharase in watermelon replant soils gradually reduced as the replanting year increased, while the inoculation with AM fungi could enhance the soil enzyme activities in different degree. For instance, at the flowering period of watermelon plants, soil proteinase and polyphenoloxidase activities were improved with AM fungal inoculation, the activity of soil proteinase was significantly enhanced from $1.13 \mathrm{NH}_{2}-\mathrm{N} \mathrm{mg} \cdot \mathrm{g}^{-1}$ to $1.36 \mathrm{NH}_{2}-\mathrm{N} \mathrm{mg} \cdot \mathrm{g}^{-1}$ in replant soil with 3 replanting years. AM fungi promoted the activity of soil polyphenoloxidase in every replant soils compared with controls, soil urease and saccharase activities were also increased in some degree (Table 4). The soil proteinase, polyphenoloxidase, urease, and saccharase activities at the fruit setting stage of watermelon plants were higher than that at the flowering period. In each replant soil, AM fungal inoculation showed the greatest effects on increasing the soil polyphenoloxidase, and saccharase activities (Table 5). At the harvesting time of watermelon, activities of soil proteinase, polyphenoloxidase, urease, and saccharase were low, while the one with AM fungal inoculation was still higher than that of controls (Table 6).

Table 4 Effects of AM fungi on soil enzyme activities of watermelon replanting at the flowering period of watermelon plants

\begin{tabular}{ccccc}
\hline Treatments & $\begin{array}{c}\text { Proteases } \\
\left(\mathrm{NH}_{2}-\mathrm{N} \mathrm{mg} \cdot \mathrm{g}^{-1}\right)\end{array}$ & $\begin{array}{c}\text { Polyphenoloxidase } \\
\left(\text { Gallicin } \mathrm{mg} \cdot \mathrm{g}^{-1}\right)\end{array}$ & $\begin{array}{c}\text { Urease } \\
\left(\mathrm{NH}_{3}-\mathrm{N} \mathrm{mg} \cdot \mathrm{g}^{-1}\right)\end{array}$ & $\begin{array}{c}\text { Saccharase } \\
\left(\text { Glucose } \mathrm{mg} \cdot \mathrm{g}^{-1}\right)\end{array}$ \\
\hline 3-CK & $1.13 \mathrm{~b}$ & $0.47 \mathrm{~b}$ & $0.32 \mathrm{ab}$ & $0.35 \mathrm{a}$ \\
3-AM & $1.36 \mathrm{a}$ & $0.80 \mathrm{a}$ & $0.35 \mathrm{ab}$ & $0.37 \mathrm{a}$ \\
7-CK & $1.03 \mathrm{~cd}$ & $0.43 \mathrm{~b}$ & $0.33 \mathrm{ab}$ & $0.20 \mathrm{~b}$ \\
7-AM & $1.08 \mathrm{bc}$ & $0.77 \mathrm{a}$ & $0.38 \mathrm{a}$ & $0.21 \mathrm{~b}$ \\
12-CK & $0.99 \mathrm{~d}$ & $0.30 \mathrm{c}$ & $0.29 \mathrm{~b}$ & $0.12 \mathrm{~cd}$ \\
12-AM & $1.07 \mathrm{bc}$ & $0.41 \mathrm{~b}$ & $0.32 \mathrm{~b}$ & $0.19 \mathrm{bc}$ \\
\hline
\end{tabular}

* Means in each column followed by different letters are significantly different based on LSD test $(P<0.05)$.

3-CK, replant soil with 3 replanting years; 3-AM, inoculating AM fungi in replant soil with 3 replanting years;

7-CK, replant soil with 7 replanting years; 7-AM, inoculating AM fungi in replant soil with 7 replanting years;

12-CK, replant soil with 12 replanting years; 12-AM, inoculating AM fungi in replant soil with 12 replanting years.

Table 5 Effects of AM fungi on soil enzyme activities of watermelon replanting at the fruit setting stage of watermelon plants

\begin{tabular}{|c|c|c|c|c|}
\hline Treatments & $\begin{array}{c}\text { Proteases } \\
\left(\mathrm{NH}_{2}-\mathrm{N} \mathrm{mg} \cdot \mathrm{g}^{-1}\right)\end{array}$ & $\begin{array}{c}\text { Polyphenoloxidase } \\
\left(\mathrm{mg} \cdot \mathrm{g}^{-1}\right)\end{array}$ & $\begin{array}{c}\text { Urease } \\
\left(\mathrm{NH}_{3}-\mathrm{N} \mathrm{mg} \cdot \mathrm{g}^{-1}\right) \\
\end{array}$ & $\begin{array}{c}\text { Saccharase } \\
\left(\text { Glucose } \mathrm{mg} \cdot \mathrm{g}^{-1}\right)\end{array}$ \\
\hline 3-CK & $1.35 \mathrm{~b}$ & $2.01 \mathrm{~b}$ & $0.37 \mathrm{ab}$ & $0.40 \mathrm{~b}$ \\
\hline 3-AM & $1.47 \mathrm{a}$ & $2.61 \mathrm{a}$ & $0.44 \mathrm{a}$ & $0.50 \mathrm{a}$ \\
\hline 7-CK & 1.32 bc & $1.22 \mathrm{c}$ & $0.37 \mathrm{ab}$ & 0.35 bc \\
\hline 7-AM & $1.40 \mathrm{ab}$ & $1.82 \mathrm{~b}$ & $0.40 \mathrm{ab}$ & $0.40 \mathrm{~b}$ \\
\hline 12-CK & $1.20 \mathrm{c}$ & $1.02 \mathrm{~d}$ & $0.32 \mathrm{~b}$ & $0.21 \mathrm{~d}$ \\
\hline 12-AM & $1.34 \mathrm{~b}$ & $1.49 \mathrm{c}$ & $0.42 a b$ & $0.30 \mathrm{c}$ \\
\hline
\end{tabular}

There are positive correlations between soil enzyme activity and soil microbe quantity, microbe diversity, microbe biomass, and soil animal numbers (Groffman et al., 2001; Taylor et al., 2002; Bandick and Dick, 1999). Inoculation with AM fungi enrich soil microbe quantities, equilibrate proportion of various microbes, maintain a stabilization of proper proportion of the microbes, enhance soil carbon, nitrogen, and phosphorous cycling power, thus improve the soil enzyme activity. 
Table 6 Effects of AM fungi on soil enzyme activities of watermelon replanting at the harvesting time of watermelon

\begin{tabular}{ccccc}
\hline Treatments & $\begin{array}{c}\text { Proteases } \\
\left(\mathrm{NH}_{2}-\mathrm{N} \mathrm{mg} \cdot \mathrm{g}^{-1}\right)\end{array}$ & $\begin{array}{c}\text { Polyphenoloxidase } \\
\left(\mathrm{mg} \cdot \mathrm{g}^{-1}\right)\end{array}$ & $\begin{array}{c}\text { Urease } \\
\left(\mathrm{NH}_{3}-\mathrm{N} \mathrm{mg} \cdot \mathrm{g}^{-1}\right)\end{array}$ & $\begin{array}{c}\text { Saccharase } \\
\left(\mathrm{Glucose} \mathrm{mg}^{-1}\right)\end{array}$ \\
\hline 3-CK & $1.17 \mathrm{~b}$ & $1.52 \mathrm{ab}$ & $0.35 \mathrm{a}$ & $0.30 \mathrm{ab}$ \\
3-AM & $1.34 \mathrm{a}$ & $1.64 \mathrm{a}$ & $0.39 \mathrm{a}$ & $0.36 \mathrm{a}$ \\
$7-\mathrm{CK}$ & $1.06 \mathrm{c}$ & $1.39 \mathrm{bc}$ & $0.25 \mathrm{ab}$ & $0.22 \mathrm{bc}$ \\
$7-\mathrm{AM}$ & $1.24 \mathrm{ab}$ & $1.52 \mathrm{ab}$ & $0.27 \mathrm{ab}$ & $0.30 \mathrm{ab}$ \\
$12-\mathrm{CK}$ & $1.00 \mathrm{c}$ & $0.84 \mathrm{~d}$ & $0.24 \mathrm{~b}$ & $0.14 \mathrm{c}$ \\
12-AM & $1.19 \mathrm{~b}$ & $1.18 \mathrm{c}$ & $0.33 \mathrm{a}$ & $0.26 \mathrm{~b}$ \\
\hline
\end{tabular}

* Means in each column followed by different letters are significantly different based on LSD test $(P<0.05)$.

3-CK, replant soil with 3 replanting years; 3-AM, inoculating AM fungi in replant soil with 3 replanting years;

7-CK, replant soil with 7 replanting years; 7-AM, inoculating AM fungi in replant soil with 7 replanting years;

12-CK, replant soil with 12 replanting years; 12-AM, inoculating AM fungi in replant soil with 12 replanting years.

\section{Conclusion}

The inoculation with AM fungus Glomus versiforme enhanced soil bacteria and actinomycete population, and decreased the fungal numbers, and the fungi/total microbe ratio in replanting soils, and improved soil proteinase, polyphenoloxidase, urease, and saccharase activities, compared with controls. That contributed to the relative equilibrium of the three kinds of soil microorganism populations. So, the AM fungal inoculation can reduce watermelon replant problems through effectively modifying the soil microbe population and community structure, and increasing the soil enzyme activities.

\section{Acknowledgements}

This work is from the project, which was financially supported by the National Natural Science Foundation of P.R. China (No. 30871737); Natural Science Foundation of Qingdao, Shandong Province (No. 09-1-3-57-jch)

\section{References}

Andrade, G., Linderman R.C. and Bethlenfalvay G. J. 1998. Bacterial association with the mycorrhizosphere of the arbuscular mycorrhizal fungus Glomus mossease. Plant and Soil, Vol. 202. No.1, pp.79-87.

Badri, D.V. and Vivanco, J. M. 2009. Regulation and function of root exudates. Plant Cell and Environment, Vol. 32. No.6, pp.666-681.

Bais, H. P., Broeckling C. D. and Vivanco J. M. 2008. Root exudates modulate plant-microbe interactions in the rhizosphere. In P

Karlovsky, ed, Secondary Metabolites in Soil Ecology, Soil Biology 14. Springer-Verlag, Berlin, Heidelberg, pp .241-252.

Bandick, A. K. and Dick P. 1999. Field management effects on soil enzyme activities. Soil Biology Biochemistry, Vol.31. No.11, pp. 1471-1479.

Bansal, M. and Mukerji, K. G. 1994. Positive correlation between VAM- induced changes in root exudation and mycorrhizosphere mycoflora. Mycorrhiza, Vol. 5. No.1, pp. 39-44.

Cao, H., Yang, H., Sun, B., Zhao, Q.G. 2002. Changes of microbial biomass and enzyme activities in garden soil as influenced by planting time. Soils, Vol.32. No.4, pp. 197-200. (In Chinese)

Catská, V. and Taube-Baab, H. 1994. The relationships between vesicular-arbuscular mycorrhiza and rhizosphere microflora in apple replant disease. Biologia Plantarum, Vol. 36. No.1, pp. 99-104.

Camprubí, A., Estaún, V. Nogales, A., García-Figueres, F., Pitet, M., Calvet, C. 2008. Response of the grapevine rootstock Richter 110 to inoculation with native and selected arbuscular mycorrhizal fungi and growth performance in a replant vineyard. Mycorrhiza, Vol. 18. No. 2, pp. 211-216.

Chin, C., Banske, E. M. and Mussen, G. 1994. Improving plant productivity with rhizosphere bacteria. In : Ryder, M. H., Stephens, P. M., Bbowen G D(eds). CSIRO, Australia, pp.191-193.

Groffman, P. M., Dowellb, W. H. and Myersc, J. C., Merriam, J. L. 2001. Soil microbial biomass and activity in tropical riparian forests. Soil Biology Biochemistry, Vol. 33. No. 10, pp. 1339-1348.

Guan, S.Y. 1986. Soil enzyme and its research methods. Beijing: China Agricultural Press. (In Chinese)

John, M. 2001. Microbial interactions and biocontrol in the rhizosphere. Journal of Experimental Botany, Vol.52. No.suppl.1, pp. 487-511.

Kothari, S.K., Marschner, H. and Romheld, V. 1991. Effect of a vesicular-arbuscular mycorrhizal fungus and rhizosphere microorganisms on manganese reduction in the rhizosphere and manganese concentrations in maize. New Phytologist, Vol. 117. No.4, pp. 649-655.

Linderman, R. G., Marlow, J.L. and Davis, E. A. 1996. Contribution of microbial associates of VA mycorrhizae to mycorrhiza effects on plant growth and health. In: Abstracts of ICOM I. Berkeley campus, California University, USA. 
Linderman, R. G. 1988. Mycorrhizal interaction with the rhizosphere microflora: the mcorrhizosphere effect. Phytopathology, Vol.78. No.3, pp. 366-371.

Liu, R. J. and Luo, X. S. 1994. A new method to quantify the inoculum potential of arbuscular mycorrhizal fungi. New Phytologist, Vol. 128. No. 1, 89-92.

Raj, H. and Sharma, S. D. 2009. Integration of soil solarization and chemical sterilization with beneficial microorganisms for the control of white root rot and growth of nursery apple. Scientia Horticulturae, Vol.119.No.2, pp. 126-131.

Rutto, K.L. and Mizutani, F. 2006. Peach seedling growth in replant and non-replant soils after inoculation with arbuscular mycorrhizal fungi. Soil Biology Biochemistry, Vol. 38. No. 9, pp. 2536-2542.

Scheffknecht, S., Mammerler, R. and Steinkellner, S. 2006. Root exudates of mycorrhizal tomato plants exhibit a different effect on microconidia germination of Fusarium oxysporum f. sp. lycopersici than root exudates from non-mycorrhizal tomato plants. Mycorrhiza, Vol. 16. No. 5, pp. 365-370.

Secilia, J. and Bagyaraj, D.J. 1987. Bacteria and actinomycetes associated with pot cultures of vesicular arbuscular mycorrhizas. Canadian Journal Microbial, Vol. 33. No.8, pp. 1069-1073.

Taylor, J. P., Wilson, B. and Mills, M. S. 2002. Comparison of microbial numbers and enzymatic activities in surface and subsoil using various techniques. Soil Biology Biochemistry, Vol. 34. No. 3, pp. 387-401.

Yao, H. Y., Jiao, X. D. and Wu, F. Z. 2006. Effects of continuous cucumber cropping and alternative rotations under protected cultivation on soil microbial community diversity. Plant and Soil, Vol. 284. No.1-2, pp. 195-203.

Zhao, B. and He, S. J. 2002. Microbiology Experiment. Beijing: Science Press. 2002. (In Chinese)

Zhao, M., Li, M., Wang, M. Y., Wang, Y., Zhang, X. Y. 2008. Effects of watermelon replanting on main microflora of rhizosphere and activities of soil enzymes. Microbiology China, Vol. 35. No. 8, pp. 1251-1254. (In Chinese)

Zhu, H. H., Long, L. K. and Yang, S. Z. 2005. Influence of AM fungus on Ralstonia Solanacearum Population and bacterial community structure in rhizosphere. Mycosystema, Vol. 24. No.1, pp. 137-142. (In Chinese)

\section{Biographical notes}

M. Zhao received M. Agronomy from Qingdao Agriculturtal University, Qingdao, China in 2008.

M. Li received M. Agronomy and Ph.D. from Zhejiang University in 1993 and from China Agricultural University , China in 2003, respectively. She is a Professor in the Department of Horticulture, Qingdao Agriculturtal University, Qingdao, China. Her research interests include arbuscular mycorrhiza, vegetable cultivation, and biocontrol of soil-borne diseases of vegetables.

Dr. R.J. Liu is a Professor in the Department of Agronomy and Plant Protection, Qingdao Agriculturtal University, Qingdao, China. He has nearly 30 years of experience in teaching and research. His current area of research includes diversity of arbuscular mycorrhizal fungi, biocontrol of soil-borne diseases, and bioremediation of degreded soil. He has published more than 100 papers in referred national and international journals. He has written two books on mycorrhiza. He is currently dealing with few projects sponsored by government of China.

Received May 2010

Accepted September 2010

Final acceptance in revised form September 2010 